\title{
THE EFFECT OF WORK ENVIRONTMENT ON TEACHERS' PERFORMANCE AT SMA NEGERI 1 DULUPI
}

\author{
Nur Rahmi ${ }^{1^{*}}$ \\ ${ }^{1}$ Universitas Ichsan Gorontalo, Indonesia. \\ *Corresponding author: nurrahmirahim77@gmail.com
}

\begin{abstract}
This study was conducted to determine how much the Physical Work Environment $\left(X_{1}\right)$, Non-Physical Work Environment $\left(X_{2}\right)$ affect, both simultaneously and partially, teachers' performance (Y) at SMA Negeri 1 Dulupi. This study used quantitative method and the data collection was carried out by using a questionnaire instrument. The analysis techniques used in this study was Path Analysis. From the research results, it was found that the Physical Work Environment and Non-Physical Work Environment simultaneously affected teachers' performance ( $Y$ ) at SMA Negeri 1 Dulupi with a value of 0.715 (71.5\%). The $F_{\text {count }}$ showed a result of 14.268 while the $F_{\text {table }}$ was 3.25 and the probability sig $0.000<$ probability $\mathrm{a}=0.05$. This means that at the $95 \%$ confidence level, the Work Environment variable $(X)$, which consists of the Physical Work Environment $\left(X_{1}\right)$ and the Non-Physical Work Environment $\left(X_{2}\right)$, has a positive and significant effect on Teachers' Performance $(Y)$. Partially, the physical work environment has a positive and significant effect on teachers' performance of 0.619 (61.9\%), and the non-physical work environment partially has a positive and significant effect on teachers' performance of 0.247 (24.7\%).
\end{abstract}

Keywords: Physical Work environment; Non-Physical Work environment; Teachers' performance

Received June ${ }^{10 \text { th }} 2020$

Revision June ${ }^{30 \text { th }} 2020$

Accepted for Publication July ${ }^{15 t h} 2020$

\section{INTRODUCTION}

National Education aims to educate Indonesian people's life and develop Indonesian people as a whole, in this regard, professionalism of educators (teachers) is needed, as stated in the Law of the Republic of Indonesia Number 20 of 2003 on the National Education System, that the position of teachers as educators is professional position. Throughout the years, it has become a demand and a need in present day that teacher professionalism must be developed, especially in mastery of science and technology, this is so that teachers can have good quality human resources, have capabilities, and are able to compete in the increasingly competitive era.

The objectives of national education as stipulated in this law can be realized if all related parties take an active role in improving the quality of the nation's education. Qualified students as one of the final outcomes that can be cited as examples of the success of national education goals according to this law. According to Barnawi and Arifin $(2014,14)$, when we talk about the quality of students, there are many factors that may affect it including teacher's performance.

Teachers are the spearhead in the world of education. Teacher's performance in learning process is a major factor in achieving educational goals. Good teacher's performance will be reflected in the quality learning that students get from a teacher. In other words, the better the teacher's performance is, the better the learning in the classroom will be. Rusman $(2012,3)$ states that learning is a process of interaction between student and teachers and 
learning resources in a learning environment. Learning must be student-centered because the subject of learning is students (Suprijono 2009, 13).

The work environment has an influence on teacher's performance, this is supported by the opinion of Nitisemito $(2006,109)$ that the work environment is everything that is around the workspace and which can affect teacher in carrying out assigned tasks, if the work environment is favorable, it will affect teacher's satisfaction and enthusiasm.

The conditions of the work environment are said to be good or appropriate if human can carry out activities in an optimal, healthy, safe and comfortable manner. The consequences of the work environment can be seen in the long term. Furthermore, an unfavorable work environment can demand more labor and time and does not support the design of an efficient work system.

The work environment is divided into two, such as; the physical and non-physical environments. Sedarmayanti $(2011,26)$ explains that the physical environment is all physical conditions around the workplace that can affect teachers either directly or indirectly. The work environment is more focused on the physical condition of the workplace because in the absence of interference in the work environment, the teacher will be able to work well (Ferina, 2008) in Lestari and Sriathi (2013). Thus, it can be concluded that the physical environment is everything that is around the teacher that can be seen and felt then has both negative and positive side effects on the results of their work.

Teachers' performance at SMA Negeri 1 Dulupi is quite good, although it can be said that it is not evenly distributed. From the initial observations of the short interview research with the leader (the principal) and several employees, the researcher saw that there were still some teachers who had less than optimal or poor performance. There are still teachers who are often coming late to school; even the teacher in question only arrives after their lessons are almost over. This resulted in the concerned teacher does not provide maximal lesson material to his students. Another example, there are teachers who have not master the learning methods, so that they seem monotonous in presenting subject matter, are less skilled and less creative in making or creating learning media. There are also teachers who, when giving assignments to students, are sometimes not followed by feedback regarding the evaluation results of the assignment. The classroom atmosphere is also often noisy because of the inability of a teacher to manage the class. This caused the students' atmosphere to become rowdy and out of control.

The issue of teachers' performance that has not been explored as described above in the researcher's observation is thought to have something to do with the work environment at school that is not yet supportive. SMA Negeri 1 Dulupi is still inadequate in terms of facilities and infrastructure. Classrooms are still limited, supporting equipment such as laboratories for experiment or practice are also incomplete. Other conditions, for example, the existence of an income gap between employees and teachers, between contract teachers and teachers with civil servant status causes the level of motivation to differ.

Several previous studies have resulted in conclusions about physical and non-physical work environments that affect teachers' performance. Singgih Mahendra (2015) with his research entitled "The Effect of the Physical Environment on Performance in Learning at R.A. Kartini Fostered Area Primary School, Kutoarjo District, Porwerejo Regency, in Central Java. The result of the research from Singgih Mahendra found that the physical environment has an effect on teacher's performance in learning. The physical work environment has an effect of $7.4 \%$, while the other $92.6 \%$ is influenced by other factors outside the physical environment.

Hendro Setyono and Ahmad Sudjadi (2009) in a research journal publication with a topic that is more or less the same "The Effect of Teacher competency, Incentives and the 
Physical Work Environment on Teacher's Performance at SMA Negeri 1 Patimuan, Cilacap Regency" resulted in a conclusion that teacher competency, incentives, and physical work environment have positive influence on teacher's performance. This means that if teacher competency, incentives and the physical work environment are improved, it will improve teacher's performance. The research similarity between the previous research and this study lies in the physical environment variables.

\section{LITERATURE}

\section{Environment}

Dalyono (2007: 129) in Heryati and Muhsin (2014: 178) explains that the environment is all materials and stimuli inside and outside the individual, physiological, psychological, and sociocultural. Umam (2014: 226) states that "the environment is everything that is outside the system".

The environment consists of the outer environment and the inner environment. Heryati and Muhsin (2014: 178) explain that the external environment is defined as a combination of geographic and socio-economic factors affecting the relationship of individuals, groups and organizations. There is also an internal environment which is the basic building material and the availability of equipment to support individual, group and organizational tasks.

\section{Physical Work Environment}

Sedarmayanti (2011: 26) explains that the physical work environment is all physical conditions that exist around the workplace that can affect teachers either directly or indirectly. According to Scott (1981) in Torang (2014: 27), the physical work environment is all forms of dependent relationships that can make organizations survive around the system in which it is placed.

Sedarmayanti (2011: 26) explains that "the physical work environment is divided into two, such as; (1) work environment that is directly related to employees (such as work centers, chairs, desks, etc.), (2) intermediary work environments, can also called the work environment that affects the human condition, for example: temperature, humidity, air circulation, lighting, noise, color and others".

\section{Non-Physical Work Environment}

Sedarmayanti (2011: 26) explains that the non-physical environment is all conditions that occur related to work relationships, both relationships with superiors and with fellow colleagues. Schools should be able to reflect conditions that support cooperation between teachers and superiors and colleagues. The conditions that should be created are a kinship atmosphere, good communication, and self-control. Therefore, the work environment must be handled or designed to be conducive for workers to carry out activities in a safe and comfortable manner (Barnawi and Arifin, 2014: 54).

The work environment in the organization must be considered and regulated in such a way as to create a favorable atmosphere which in turn can encourage enthusiasm to work more actively, remain nurtured, not only for the concerned employees but also for all employees in the organization. To create a conducive and comfortable work environment, at least two things are needed, such as the teacher and a good relationship between teachers and parents and the community around them (Mulyasa 2013: 193).

From some of these opinions it is concluded that a conducive work environment will increase work productivity, and teachers needs to be well aware of this. Every teacher has the same obligations, one of which is to create a comfortable atmosphere in their work environment. 
Designing a conducive work environment is very important for organizations. According to Darmodiharjo (2005: 44), a conducive work environment must meet 5 requirements, as follows:

1. Security

A sense of security will create calmness and will encourage work enthusiasm. In this case the security in question is the security of private property, because personal security and safety are very important things.

2. Environmental Hygiene

Organizations should always keep the environment clean; a clean work environment can affect a person's health and psyche. For someone who is normal, a clean work environment will definitely make you feel good. This can influence someone to work more enthusiastically and passionately.

3. Discipline

Every leader and officer has rules set by the institution, for the orderly conduct of duties, responsibilities that have been extended to leaders and officers.

4. Fineness

For the workspace, it should use colorful or soft color. Color and composition need attention. This is because it affects the morale and enthusiasm of the employees. A good workspace must be able to place things neatly and have space for easy movement.

5. Kinship

Interaction between employees, employees with leaders and leaders with leaders openly can create a sense of kinship so as to create openness in work problems.

\section{Performance}

Ishak, (2018) states that performance is a benchmark that can be used to determine the comparison of the results of the implementation of tasks, responsibilities given by the organization in a certain period and relatively used to measure work performance or organizational performance.

Hasibuan (2012: 65) states that performance is meant as a result of work achieved by a person in carrying out their duties on skills, effort, and opportunity. While performance according to Mangkunegara (2014: 09) is the result of work in quality and quantity achieved by an employee in carrying out their duties in accordance with the responsibilities given to them.

So, it can be concluded that performance is an achievement or can be interpreted as an employee's work performance in activities or activities that have been planned in advance both regarding the quantity and quality achieved in carrying out their tasks in accordance with the responsibilities assigned to them.

\section{Teacher competency}

Based on the Law of the Minister of National Education of the Republic of Indonesia Number 16 of 2007 on Academic Qualification Standards and Teacher Competencies, it was explained that the Teacher Competency Standards were developed as a whole from 4 main competencies, such as: (1) pedagogical competence, (2) personality competence, (3) social competence, and (4) professional competence. The four competencies are integrated in teacher's performance.

\section{Teacher's Performance}

Teachers are at the forefront of educational success and are seen as people who play an important role in achieving educational goals. Therefore, teacher's performance is very important to pay attention to and evaluate. 
Barnawi and Arifin (2014: 14) define teacher's performance as the level of teacher's success in carrying out educational tasks in accordance with their responsibilities and authorities based on performance standards. Rachmawati and Daryanto (2013: 16) define teacher's performance as "the ability shown by the teacher in carrying out a task or job."

From this opinion, it can be concluded that teacher's performance is the ability and success of teachers in carrying out their duties and responsibilities as professional based on performance standards. Teacher's performance can describe the existence of an action that they display during learning activities.

\section{RESEARCH METHOD}

The research was conducted by using quantitative method. According to Sugiyono (2010), quantitative research method can be interpreted as research based on the philosophy of positivism, used to examine certain populations or samples, in the form of numbers and the analysis uses statistics. The approach in this study used survey research, where research was used to explain causal relationships and hypothesis testing. This study took a sample of teachers with a questionnaire as the main data collection tool

\section{Operationalization of Variables}

According to Nazir $(2003,149)$ what is meant by operational variables is a research element that tells how to measure variables. Meanwhile, variable is a concept that has various values. The research variable is the work environment $(\mathrm{X})$ which consists of the Physical Work Environment $\left(\mathrm{X}_{1}\right)$, and the Non-Physical Work Environment $\left(\mathrm{X}_{2}\right)$, on Teacher's performance (Y).

In order to get a clearer picture of this research, first it is necessary to operate the variables as mentioned in the background of the problem and a framework that aims to determine the indicators of the relevant variables in order to make it easier to determine the instrument or variable measurement. The indicators of the variables mentioned above can be seen in the table below:

Table 1. Operationalization of $\mathrm{X}$

\begin{tabular}{|c|c|c|c|}
\hline Variable & Sub Variable & Indicator & Scale \\
\hline & Physical Work Environment $\left(\mathrm{X}_{1}\right)$ & $\begin{array}{l}\text { 1. Lighting } \\
\text { 2. Air } \\
\text { 3. Colour } \\
\text { 4. Hygiene } \\
\text { 5. Noise }\end{array}$ & ORDINAL \\
\hline $\begin{array}{l}\text { Work Environment } \\
\qquad(\mathrm{X})\end{array}$ & $\begin{array}{l}\text { Non- Physical Work Environment } \\
\qquad\left(\mathrm{X}_{2}\right)\end{array}$ & $\begin{array}{l}\text { 1. There is a sense of security } \\
\text { 2. Good relationship with Superintendent } \\
\text { 3. Good relationship co-workers } \\
\text { 4. There is a satisfaction among } \\
\text { employees }\end{array}$ & ORDINAL \\
\hline
\end{tabular}

Table 2. Operationalization of Y

\begin{tabular}{clll}
\hline Variable & \multicolumn{1}{c}{ Dimension } & \multicolumn{1}{c}{ Indicator } & Scale \\
\hline & & $\begin{array}{l}\text { 1. A competency to design and plan the lesson } \\
\text { 2. Mastery of learning material that will be } \\
\text { taught }\end{array}$ & ORDINAL \\
$\begin{array}{lll}\text { Teacher's Performance } \\
(\mathrm{Y})\end{array}$ & $\begin{array}{l}\text { 1. Mastery of teaching method and strategy } \\
\text { Teaching }\end{array}$ & 2. Giving assignment to students & ORDINAL
\end{tabular}


In conducting the test, each variable WAS measured BY a Likert scale. This Likert scale provides a score value on the answer item. The scoring for each item in response to the questions given to the respondents of this study then were referred to Sugiyono's statement (2010'86), the answers to each instrument using the Likert scale have a gradient from very positive to very negative which can be in the form of words.

\section{Population}

Sugiyono (2010), suggests that population is a generalization consisting of objects that have certain qualities and characteristics that are determined by researchers to be studied and then draw conclusions. The population in this study were all teachers, 39 people in total, who were teaching at SMA Negeri 1 Dulupi, both civil servants and non-civil servants.

\section{Sample}

According to Sugiyono $(2015,62)$, the sample is part of the number of characteristics possessed by the population. If the population is large, and it is impossible for the researcher to study everything in the population, for example, because of limited funds, energy and time, the researcher can use a sample taken from that population. What is found from the sample, the conclusions will be applicable to the population. For this reason, the sample taken from the population must be truly representative. Because the population is considered a sample too, the number of samples in this study are 39 SMA Dulupi teachers, both civil servants and non-civil servants."

\section{Sampling Technique}

The sampling technique used in this study were survey methods or saturated samples. According to Sugiyono $(2015,62)$ that the saturated sample method is chosen when all members of the population are used as samples at once. It is used when the population is relatively small, another term for saturated sample is census where all members of the population are taken as sample."

\section{Research Procedure Validity Test}

The validity test is used to measure the validity of the questionnaire. A questionnaire is said to be valid if the questions in the questionnaire are able to reveal something that will be measured by the questionnaire. To interpret the results of the validity test, the criteria used are:

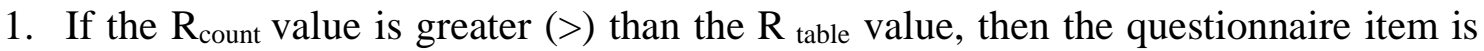
declared valid and can be used.

2. If the $\mathbf{R}_{\text {count }}$ value is smaller $(<)$ than the $\mathbf{R}_{\text {table }}$ value, then the questionnaire item is declared invalid and cannot be used"

\section{Reliability Test}

The reliability test is the level of how much a measuring instrument measures stably and consistently, meaning whether a measuring instrument used is reliable and remains consistent if the measurement is repeated. The level of reliability is indicated by the coefficient that is the reliability coefficient. Reliability testing is carried out using Cronbach alpha which is more than 0.60 that indicates the reliability of the instrument and if the alpha value is $<0.60$ it is said to be unreliable (Ghozali, 2005). 


\section{Data Conversion}

In order to process the data into path analysis, the ordinal data obtained in the form of a Likert scale which is still in the form of ordinal data must first be transformed into interval data using the Method of Successive Interval (MSI).

\section{Data Analysis Method}

\section{Model/Illustration}

To ensure the effect of sub-variables on performance, path analysis testing is carried out, for ordinal data that has been converted to an interval scale through the Method of Successive Interval (MSI). This path analysis is used by considering that the relationship pattern between variables in the study is correlative and causality.

The research hypothesis is explained through the structure of the relationship between the independent variable and the dependent variable with a diagram that can be seen in the following path structure:

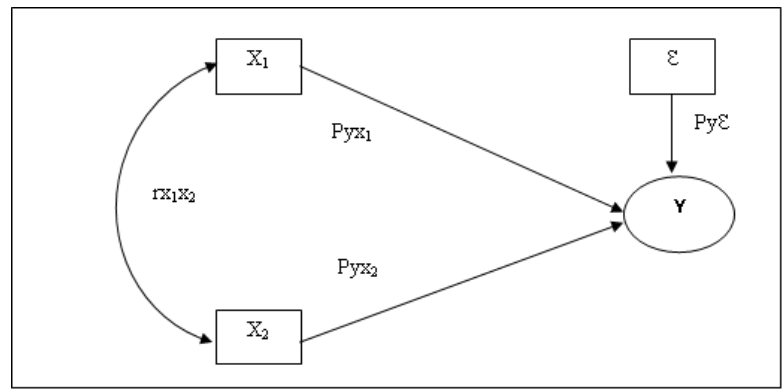

Figure 1. Path Analysis Structure

From the picture above, it can be seen in the following equation:

$\mathrm{Y}=\mathrm{Pyx} 1+\mathrm{Pyx} 2+\mathrm{Py} \dot{\varepsilon}$

In which:

$\mathrm{X}_{1}$ : Physical Work Environment

$\mathrm{X}_{2}$ : Non-Physical Work Environment

Y: Teachers' performance

$\dot{\varepsilon}$ : Other variable that affect $\mathrm{Y}$

r: Correlation between $X$ variables

PY: Path coefficients for direct effect"

\section{Hypothesis Testing Steps}

In accordance with the hypothesis and research design that has been stated previously, the hypothesis testing using path analysis were carried out with the following steps:

1. Creating a structural equation:

$$
\mathrm{Y}=\mathrm{Pyx} 1+\mathrm{Pyx} 2+\mathrm{Pyc}
$$

2. Calculate the correlation matrix between $X_{1}, X_{2}$ and $Y$

3. Calculate the correlation matrix between exogenous variables

4. Calculate the inverse matrix $\mathrm{R}_{1-1}$

5. Calculate the Pyxi path coefficient ( $\mathrm{i}=1$ and 2$)$

6. Calculate $R_{2}$, namely the coefficient which states the total determination of $X_{1}, X_{2}$, against $\mathrm{Y}$

7. Calculate the effect of other variables (Pẏُ)

8. Testing the path coefficient is also a research hypothesis testing. The statistics used are the $\mathrm{F}$ test and the $\mathrm{T}$ test with the following conditions:

\section{f-Test}


It is used to test the effect of the independent variable, jointly or simultaneously on the dependent variable. The f-test criteria are as follows:

1. If $\mathrm{f}_{\text {count }}<\mathrm{f}_{\text {table, }}$, then $\mathrm{H}_{\mathrm{a}}$ is accepted and $\mathrm{H}_{\mathrm{o}}$ is rejected, it means that there is no simultaneous effect between the independent variables on the dependent variable.

2. If $f_{\text {count }}>f_{\text {table, }}$ then $H_{o}$ is accepted and $H_{a}$ is rejected, meaning that there is a simultaneous effect between the independent variables on the dependent variable. The $\mathrm{F}$ test can be done only by looking at the F significance value in the output of the regression analysis. If the F significance value is smaller than $\alpha(0.05)$, it can be said that there is a significant effect between the independent variables on the dependent variable simultaneously.

t-Test

It is used to test the effect of the independent variable partially on the dependent variable. The t-test criteria are as follows:

1. If $t_{\text {count }}<t_{\text {table, }}$, then $\mathrm{H}_{\mathrm{o}}$ is rejected and $\mathrm{H}_{\mathrm{a}}$ is accepted, it means that there is no effect between the independent variables partially on the dependent variable.

2. If $t_{\text {count }}>t_{\text {table }}$, then $\mathrm{H}_{\mathrm{a}}$ is rejected and $\mathrm{H}_{\mathrm{o}}$ is accepted, it means that there is an effect between the independent variables partially on the dependent variable. The t-test can be done only by looking at the $t$ significance value of each variable in the output of the regression analysis. If the significance value of $t$ is smaller than $\alpha(0.05)$, it can be said that there is a significant effect between the independent variables on the dependent variable.

\section{FINDINGS AND DISCUSSION}

\section{Validity and Reliability Test Results}

To determine the level of validity, the research instrument was given to 39 respondents. The research instrument is considered valid if the $r_{\text {count }}>r_{\text {table }}$ and reliable if the Cronbach's Alpha value is $>0.6$.

\section{a. Validity Test and Reliability Test of Physical Work Environment Variables $\left(\mathrm{X}_{1}\right)$}

Based on the result of data analysis in the attachment of the Validity Test and Reliability Test, the result is shown in Table 3 below:

Table 3. The Result of Validity Test and Reliability Test of Physical Work Environment Variables $\left(\mathbf{X}_{1}\right)$

\begin{tabular}{|c|c|c|c|c|c|c|c|}
\hline \multirow[t]{2}{*}{ Variable } & \multirow[t]{2}{*}{ Sub Variable } & \multirow[t]{2}{*}{ Indicator } & \multicolumn{3}{|c|}{ Validity Test } & \multicolumn{2}{|c|}{ Reliability Test } \\
\hline & & & $r_{\text {count }}$ & $\mathrm{r}_{\text {table }}$ & Information & Alpha & Information \\
\hline \multirow{5}{*}{$\begin{array}{c}\text { Work } \\
\text { Environment }\end{array}$} & \multirow{5}{*}{$\begin{array}{c}\text { Physical Work } \\
\text { Environment }\end{array}$} & XI.1 & 0.567 & 0.316 & Valid & & \\
\hline & & XI.2 & 0.444 & 0.316 & Valid & \multirow{4}{*}{0.644} & \multirow{4}{*}{$<0.60=$ Reliable } \\
\hline & & XI.3 & 0.586 & 0.316 & Valid & & \\
\hline & & XI.4 & 0.48 & 0.316 & Valid & & \\
\hline & & XI.5 & 0.531 & 0.316 & Valid & & \\
\hline
\end{tabular}

Table 3 explains that all items for the Physical Work Environment $\left(\mathrm{X}_{1}\right)$ sub-variable in the questionnaire show valid results, this conclusion is based on the results of the value rcount > rtable, while the Alpha coefficient is 0.644 thus it means that all statement items in the questionnaire for the Physical Work Environment sub variable are reliable because the Cronbach's Alpha value > 0.6.

b. Validity Test and Reliability Test of Non-Physical Work Environment Variables $\left(X_{2}\right)$ Based on the results of data analysis in the attachment of the Validity and Reliability Test, the result is shown in in the following table: 
Table 4. The Result of Validity Test and Reliability Test of Non-Physical Work Environment Variables $\left(\mathrm{X}_{2}\right)$

\begin{tabular}{|c|c|c|c|c|c|c|c|}
\hline \multirow[t]{2}{*}{ Variable } & \multirow[t]{2}{*}{ Sub Variable } & \multirow[t]{2}{*}{ Indicator } & \multicolumn{3}{|c|}{ Validity Test } & \multicolumn{2}{|c|}{ Reliability Test } \\
\hline & & & $r_{\text {count }}$ & $\mathrm{r}_{\text {table }}$ & Information & Alpha & Information \\
\hline \multirow{4}{*}{$\begin{array}{c}\text { Work } \\
\text { Environment }\end{array}$} & \multirow{4}{*}{$\begin{array}{l}\text { Non-Physical Work } \\
\text { Environment }\end{array}$} & $\mathrm{X} 2.1$ & 0.694 & 0.316 & Valid & \multirow{4}{*}{0.778} & \multirow{4}{*}{$<0.60=$ Reliable } \\
\hline & & $\mathrm{X} 2.2$ & 0.534 & 0.316 & Valid & & \\
\hline & & $\mathrm{X} 2.3$ & 0.731 & 0.316 & Valid & & \\
\hline & & $\mathrm{X} 2.4$ & 0.443 & 0.316 & Valid & & \\
\hline
\end{tabular}

Table 4 explains all the items for the non-physical work environment $\left(\mathrm{X}_{2}\right)$ sub-variable in the questionnaire show valid results, this is because the value of $r_{\text {count }}>r_{\text {table, while the Alpha }}$ coefficient is 0.778 , thus it means all items in the questionnaire for the non-physical work environment sub-variable are reliable because the Cronbach's Alpha value is > 0.6.

The Result of Validity Test and Reliability Test of Teacher's Performance (Y) Based on the results of data analysis in the attachment of the Validity and Reliability Test, the result is shown in in the following table:

Table 5. The Result of Validity Test and Reliability Test of Teacher's Performance (Y)

\begin{tabular}{|c|c|c|c|c|c|c|}
\hline \multirow[t]{2}{*}{ Variable } & \multirow[t]{2}{*}{ Indicator } & \multicolumn{3}{|c|}{ Validity Test } & \multicolumn{2}{|c|}{ Reliability Test } \\
\hline & & $r_{\text {count }}$ & $\mathrm{r}_{\text {table }}$ & Information & Alpha & Information \\
\hline \multirow{6}{*}{$\begin{array}{l}\text { Teacher's } \\
\text { Performance }\end{array}$} & YI.1 & 0.524 & 0.316 & Valid & \multirow{6}{*}{0.792} & \multirow{6}{*}{$<0.60=$ Reliable } \\
\hline & YI.2 & 0.522 & 0.316 & Valid & & \\
\hline & YI.3 & 0.408 & 0.316 & Valid & & \\
\hline & YI.4 & 0.535 & 0.316 & Valid & & \\
\hline & YI.5 & 0.437 & 0.316 & Valid & & \\
\hline & YI.6 & 0.688 & 0.316 & Valid & & \\
\hline
\end{tabular}

Table 5 explains that all items for the Teacher's performance variable (Y) in the questionnaire show valid results, this decision was taken because the value $r_{\text {count }}>r_{\text {table, }}$, while the Alpha coefficient is 0.792 , thus, it means that all statement items in the questionnaire for the Teacher's Performance variable are reliable because the Cronbach's Alpha value is > 0.6.

\section{Statistical Data Analysis}

The result of statistical analysis using path analysis determines whether the independent variables either simultaneously or partially have a significant effect on the dependent variable. Based on the results of data analysis of 39 respondents using path analysis, the following equation is obtained:

$$
\hat{\mathbf{Y}}=0.619 \mathrm{X}_{1}+\mathbf{0 . 2 4 7} \mathrm{X}_{2}+\mathbf{0 . 2 8 5 \varepsilon}
$$

From the equation above, it shows that the coefficient of the independent variable, namely the Physical Work Environment $\left(\mathrm{X}_{1}\right)$ as measured on teacher's performance (Y), had a positive and significant effect. The direct effect of the physical work environment on teacher's performance is 0.619 or $61.9 \%$.

$\mathrm{X}_{2}=0.247$ indicates that the Non-Physical Work Environment $\left(\mathrm{X}_{2}\right)$, which is measured on teacher's performance (Y), has a positive and significant effect on teacher's Performance. The direct effect of the Non-Physical Work Environment $\left(\mathrm{X}_{2}\right)$ on teacher's performance is 0.247 or $24.7 \%$. While $\varepsilon=0.285$ indicates that there are other variables which have not been examined in this study at $28.5 \%$.

Taking into account the result of the path analysis in the appendix, the results of the analysis can be interpreted that the Coefficient of Determination ( $\left.R_{\text {Square }}\right)$ is 0.715 , this means that about $71.5 \%$ of the existing effect on teacher's performance were caused by the Physical 
Work Environment variable and Non Physical Work Environment. There are still about 0.285 or $28.5 \%$ effect which determined by other variables and still need further research.

Based on the results of path analysis, the relationship between variables can be seen in the figure below:

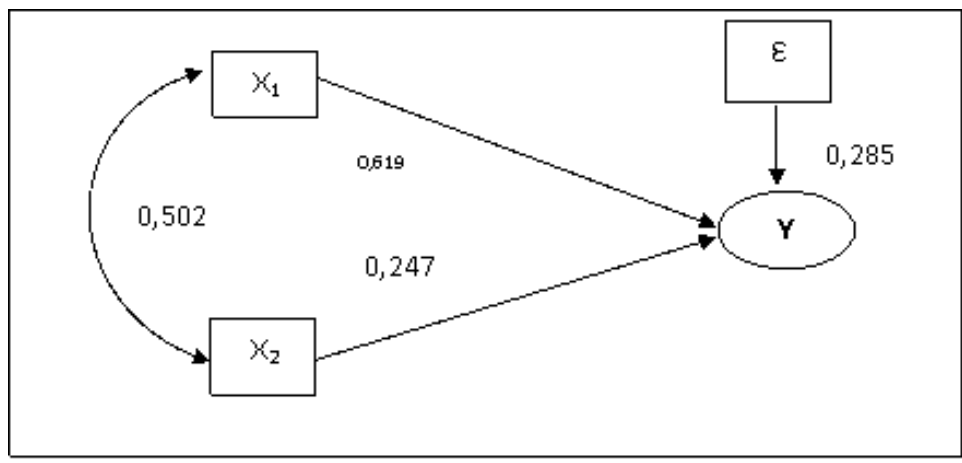

Figure 2. Estimation result of Path analysis

As a result of the analysis of the independent variables, the dominant effect caused by the Physical Work Environment variable $\left(\mathrm{X}_{1}\right)$ with a value of 0.619 and the Non-physical Work Environment of 0.247 on Teacher's Performance (Y). The results can be summarized as in the following table:

Table 6. Composition of the Effect of Variable X on Y

\begin{tabular}{ccccc}
\hline \multirow{2}{*}{ Variable } & \multicolumn{3}{c}{ Effect } & \multirow{2}{*}{ Simultaneous Contribution $\left(\mathrm{R}_{2}\right)$} \\
\cline { 2 - 4 } & Direct & Indirect & Total & \\
\hline $\mathrm{X}_{1}$ & 0.619 & - & $61.9 \&$ & - \\
$\mathrm{X}_{2}$ & 0.247 & - & $24.7 \%$ & - \\
$?$ & 0.285 & - & $28.5 \%$ & - \\
$\mathrm{X}_{1}, \mathrm{X}_{2}$ & - & - & - & $71.5 \%$ \\
\hline \multicolumn{5}{c}{ Source: The Result of Data Analysis }
\end{tabular}

\section{Hypothesis test}

a. Work Environment $(X)$ which consists of Physical Work Environment $\left(X_{1}\right)$ and Non-Physical Work Environment $\left(\mathbf{X}_{2}\right)$ Simultaneously Affects Teacher's Performance (Y)

The result of the $f_{\text {count }}$ shows a result of 14.268 while the $f_{\text {table }}$ is 3.25 and the sig $0.000<$ probability $a=0.05$. This means that at the $95 \%$ confidence level, the Work Environment variable $(\mathrm{X})$ which consists of the Physical Work Environment $\left(\mathrm{X}_{1}\right)$ and the Non-Physical Work Environment $\left(\mathrm{X}_{2}\right)$ has a positive and significant effect on Teacher's Performance (Y).

This means that the hypothesis which states that the Work Environment consisting of the Physical Work Environment $\left(\mathrm{X}_{1}\right)$ and the Non-Physical Work Environment $\left(\mathrm{X}_{2}\right)$ has a simultaneous effect on Teacher's Performance (Y) at SMA Negeri 1 Dulupi is accepted.

b. Physical Work Environment $\left(\mathrm{X}_{1}\right)$ partially has a Positive and Significant Effect on Teacher's Performance (Y).

The t-test show a result of confidence level at 95\%, statistically, it shows that the Work Environment variable $(\mathrm{X})$ which consists of the Physical Work Environment $\left(\mathrm{X}_{1}\right)$ has a positive and significant effect on Teacher's Performance (Y) with a sig value of $0.000<$ probability $\mathrm{a}=0.05$. Therefore, the hypothesis which states that the Work Environment which consists of Physical Work Environment $\left(\mathrm{X}_{1}\right)$ has a partial effect on Teacher's performance (Y) at SMA Negeri 1 Dulupi is accepted.

c. Non-Physical Work Environment $\left(\mathrm{X}_{2}\right)$ partially has a Positive and Significant Effect on Teacher's Performance (Y). 
The t-test show a result of confidence level at 95\%, statistically, it shows that the Work Environment variable $(\mathrm{X})$ which consists of the Non-Physical Work Environment $\left(\mathrm{X}_{2}\right)$ has a positive and significant effect on Teacher's Performance (Y) with a value of sig $0.000<$ probability $a=0.05$. Therefore, the hypothesis which states that the Work Environment which consists of the Non-Physical Work Environment $\left(\mathrm{X}_{2}\right)$ has a partial effect on Teacher's Performance (Y) at SMA Negeri 1 Dulupi is accepted.

d. Correlation between $X$ Variables

\section{1) $X_{1}$ Correlation}

Correlation of Physical Work Environment $\left(\mathrm{X}_{1}\right)$ and Non-Physical Work Environment $\left(\mathrm{X}_{2}\right)$ is 0.502 . This shows that there is a high relationship between the two variables.

\section{2) $X_{2}$ Correlation}

The correlation of the Non-Physical Work Environment $\left(\mathrm{X}_{2}\right)$ and the Physical Work Environment $\left(\mathrm{X}_{1}\right)$ is 0.502 . This shows that there is a high relationship between the two variables.

\section{Discussion}

\section{a. Work Environment (X) Simultaneously Affects Teacher's performance (Y)}

The results showed that the work environment has an effect on teacher's performance, this means that a clean, safe, brightly lit, well-ventilated, and not noisy work environment create a feeling of satisfaction among teachers and students and reduce boredom, thus, in this manner; it can avoid waste time and costs so that teacher's performance can increase in carrying out their duties.

The results of the research that can be stated are that there is a direct positive and significant effect simultaneously between the Physical Work Environment $\left(\mathrm{X}_{1}\right)$ and NonPhysical Work Environment $\left(\mathrm{X}_{2}\right)$ variables on Teacher's performance $(\mathrm{Y})$ at SMA Negeri 1 Dulupi of 0.715 or $71.5 \%$. This shows that the more the work environment is developed by the school, the higher the teacher's performance at SMA Negeri 1 Dulupi is.

In addition, there are external variables that affect teacher's performance e but are not included in the model such as individual factors and organizational environmental factors according to Mangkunegara $(2014,16)$ which can affect teacher's performance by 0.134 or $13.4 \%$.

Theoretically, the results of this study are in accordance with the theory by Anoraga $(2006,56)$ who states that one of the factors that workers really need in order to increase their work productivity is a good work environment. A good working environment or atmosphere will also have a good influence on all parties, either on the workers, on the leaders or on the work performance. Saydam $(2008,226)$ argues that the work environment is the entire work facilities and infrastructure surrounding employees who are doing work which can affect the implementation of the work itself. According to Schultz $(2010,405)$ work environment or conditions are all aspects of physical work, work psychology and work regulations that can affect job satisfaction and work productivity.

Wakhid $(2014,66)$ suggests that a conducive work environment provides a sense of security and allows employees to work optimally. Work environment can affect employee emotionally. If an employee enjoys the work environment, then the employee will feel at home in their workplace, carrying out their activities effectively so that work time is used efficiently. Productivity will be high and employee performance will also automatically be high. The work environment includes the work relationship between subordinates and superiors as well as the physical environment where the employees work.

This research is in line with previous researchers by Risaldin (2017) who conducted a research of the Relationship between the Work Environment and the Performance of Public Elementary School Teachers in Wawotobi District, Konawe Regency. The results of this 
study have a direct influence between the work environment and teacher's performance. This indicates that the more comfortable the work environment in the workplace results in increased teacher's performance.

Asari (2017) in a research of Relationship between Work Environment and Job Satisfaction with Teacher's performance at SMK Negeri 1 Muara Bungo showed that there was a significant positive relationship between the work environment and teacher's performance at SMK 1 Muara Bungo.

\section{b. Physical Work Environment (X1) partially has a positive and significant effect on Teacher's performance (Y).}

Based on the results of research on 39 respondents, it shows that partially there is a positive and significant direct effect between the Physical Work Environment $\left(\mathrm{X}_{1}\right)$ variable on Teacher's performance (Y) of 0.619 or $61.9 \%$. This shows that the more physical work environment is developed by schools, the higher the teacher's performance in carrying out their duties.

The results of this study indicate that the physical work environment is more dominant than the non-physical work environment on teacher's performance. This can happen because the results of the respondents' answers in the questionnaire indicate that the physical work environment variables are in a very high category because all the statement items answered by the respondents mostly answered with strongly agree, which means that the lighting in the workplace is very supportive of the atmosphere in teaching, air circulation is functioning properly so that it makes teaching comfortable, and the hygience of the work environment is very well maintained, even the noise caused by vehicles passing on the road is heard not at all because the location of the teaching place is far from the road, even though there are still some teachers who answered sometimes this was due to the noise in the school which still happened caused by the students themselves, such as noise in the room when there was no teaching and learning process.

This is in line with the theory by Sedarmayanti $(2011,26)$ who explained that the physical work environment is all physical conditions that exist around the workplace that can affect teachers either directly or indirectly. According to Scott $(1981)$ in Torang $(2014,27)$ the physical work environment is all forms of dependency relationships that can make an organization survive on the system in which it is located.

Meanwhile, Barnawi and Arifin $(2014,54)$ explain that there are several factors that affect the physical environment, including lighting, color, air, hygiene, noise, and security.

\section{c. Non-Physical Work Environment (X2) partially has a positive and significant effect on Teacher's performance ( $Y$ )}

Based on the results of research on 39 respondents, it shows that partially there is a positive and significant direct influence between the Non-Physical Work Environment $\left(\mathrm{X}_{2}\right)$ variable on Teacher's performance (Y) of 0.247 or $24.7 \%$. This shows that a conducive work environment will increase work productivity, and every teacher needs to be aware of it. Every teacher has the same obligations, one of which is to create a comfortable atmosphere in their work environment.

The result shows that the non-physical work environment had a lower effect than the physical work environment on teacher's performance, this happened because based on the results of the respondents' answers, there were still respondents who had less communication with their superiors, among colleagues, and there were still lack of facilities and infrastructure like a library for students to study.

This is in accordance with the theory by Sedarmayanti $(2011,26)$ who explains that the non-physical environment is all conditions that occur related to work relationships, both relationships with superiors and with fellow colleagues. Schools should be able to reflect 
conditions that support cooperation between teachers and superiors and colleagues. The conditions that should be created are a kinship atmosphere, good communication, and selfcontrol.

The work environment in the organization must be considered and regulated in such a way as to create a favorable atmosphere which in turn can encourage enthusiasm to work more actively, remain nurtured, not only for the concerned employees but also for all employees in the organization. To create a conducive and comfortable work environment, two things are needed, such as; the teacher and a good relationship between the teacher and parents and the community around them (Mulyasa 2013, 193).

\section{CONCLUSION}

Based on the research results that have been described in the previous paragraph, the conclusion is as follows:

1. Work Environment which includes Physical Work Environment $\left(\mathrm{X}_{1}\right)$ and Non-Physical Work Environment $\left(\mathrm{X}_{2}\right)$ simultaneously has a positive and significant effect on Teacher's performance at SMA Negeri 1 Dulupi. This shows that the proposed hypothesis is accepted.

2. Work Environment which includes Physical Work Environment $\left(\mathrm{X}_{1)}\right.$ partially has a positive and significant effect on Teacher's performance at SMA Negeri 1 Dulupi. This shows that the proposed hypothesis is accepted.

3. The work environment which includes the non-physical work environment $\left(\mathrm{X}_{2}\right)$ partially has a positive and significant effect on teacher's performance at SMA Negeri 1 Dulupi. This shows that the proposed hypothesis is accepted.

\section{REFERENCES}

As'ari. (2008). Association education communication and tehnologi.

Barnawi dan Mohammad Arifin. (2014). Kinerja Guru Profesional. Yogyakarta: Ar-Ruzz Media.

Direktorat Tenaga Kependidikan Dirjen PMPATK. (2008). Penilaian Kinerja Guru: Jakarta.

Ferina, (2008). Pengaruh Kepemimpinan, Lingkungan Kerja Fisik dan Kompensasi terhadap Kinerja Karyawan Pada PT. Pertamina. Journal Ekonomi dan Bisnis. Yogyakarta.

Hasibuan, Malayu.( 2014). Manajemen Sumber Daya Manusia. Bumi Aksara. Jakarta.

Heryati, Yeti dan Mumuh Muhsin. (2014). Manajemen Sumber Daya Pendidikan. Bandung: Pustakastia.

Ishak, P. (2018). Pengaruh Independensi Auditor, Emotional Intelligence, Spiritual Intelligence Terhadap Perilaku Etis Auditor dan Kinerja Auditor. ATESTASI: Jurnal Ilmiah Akuntansi, 1(1), 85-98.

Mangkunegara, Anwar Prabu. (2014). Sumber Daya Manusia Perusahaan. Remaja Rosdakarya. Bandung.

Moch Nazir, (2003). Metodelogi Penelitian. Penerbit Ghalia Indonesia. Jakarta.

Mulyasa, E. (2013). Uji Kompetensi dan Penilaian Kinerja Guru. Bandung: PT Remaja Rosdakarya.

Nitisemito, Alex S. (2006). Manajemen Personalia (Manajemen Sumber Daya Manusia). Jakarta: Ghalia Indonesia. 
Penerbit Fakultas Ekonomi Universitas Indonesia.

Rachmawati, Tutik dan Daryanto. (2013). Penilaian Kinerja Guru dan Angka Kreditnya. Yogyakarta: Penerbit Gava Media.

Rivai Veithzal,( 2009). Manajemen Sumber Daya Manusia untuk Perusahaan. Jakarta: Raja Grafindo.

Rusman. (2012). Model-Model Pembelajaran Mengembangkan Profesionalisme Guru. Jakarta: PT Raja Grafindo Persada.

Sedarmayanti.( 2011). Tata Kerja dan Produktivitas Kerja. Bandung: Mandar Maju.

Siagian. (2014). Manajemen Sumber Daya Manusia. Jakarta: PT. Bumi Aksara.

Simanjuntak P.J. (2001). Manajemen dan Evaluasi Kerja. Jakarta: Lembaga

Slamet. (2007). Manajemen Sumber Daya Manusia. Unnes Press. Semarang.

Sofyan Yamin Dkk. (2011). Regresi dan Korelasi dalam Genggaman Anda. Salemba Empat: Jakarta.

Sugiyono. (2010). Metode Penelitian Pendidikan Pendekatan Kuantitatif, Kualitatif, dan $R n D$. Bandung. Alfabeta.

Supardi. (2013.) Kinerja Guru. Rajawali pers. Jakarta.

Suprijono, Agus. (2009). Cooperative Learning Teori dan Aplikasi Paikem. Yogyakarta: Pustaka Pelajar.

Torang, Syamsir. (2014). Organisasi dan Manajemen. Bandung: Alfabeta.

Umam, Khaerul. (2014). Manajemen Perkantoran Reverensi untuk Para Akademisi dan Praktisi. Bandung: Pustaka Setia. 